This document is the accepted manuscript version of the following article:

Luh, S., Budinis, S., Giarola, S., Schmidt, T. J., \& Hawkes, A. (2019). Long-term development of the industrial sector - case study about electrification, fuel switching, and CCS in the USA. Computers and Chemical Engineering. https://doi.org/10.1016/j.compchemeng.2019.106602

This manuscript version is made available under the CC-BY-NC-ND 4.0 1icense http://creativecommons.org/ 1icenses/by-nc-nd/4.0/

\title{
Long-term Development of the Industrial Sector - Case Study about Electrification, Fuel Switching, and CCS in the USA
}

\author{
Sandro Luh a, b, 1 (Sandro.Luh@psi.ch) \\ Sara Budinis ${ }^{\text {a, * }}$ (s.budinis11@imperial.ac.uk) \\ Sara Giarola c (s.giarola10@imperial.ac.uk) \\ Thomas J. Schmidt d, e (thomasjustus.schmidt@psi.ch) \\ Adam Hawkes a (a.hawkes@imperial.ac.uk) \\ ${ }^{a}$ Imperial College London, Dpt. of Chemical Engineering, South Kensington Campus, London SW7 2AZ, United \\ Kingdom
}

${ }^{b}$ ETH Zurich, Dpt. of Mechanical and Process Engineering, Raemistrasse 101, 8092 Zurich, Switzerland

'Imperial College London, Dpt. of Earth Science and Engineering, South Kensington Campus, London SW7 2AZ, United Kingdom

${ }^{d}$ ETH Zurich, Laboratory of Physical Chemistry, Dpt. of Chemistry and Applied Biosciences, Raemistrasse 101, 8092 Zurich, Switzerland

${ }^{e}$ Paul Scherrer Institute, Electrochemistry Laboratory, 5232 Villigen PSI, Switzerland

*s.budinis11@imperial.ac.uk

The first two authors, Sandro Luh and Sara Budinis, have contributed in equal measure to the paper.

\begin{abstract}
In the urgent quest for solutions to mitigate climate change, the industry is one of the most challenging sectors to decarbonize. In this work, a novel simulation framework is presented to model the investment decisions in industry, the Industrial Sector Module (ISM) of the ModUlar energy system Simulation Environment (MUSE). This work uses the ISM to quantify effects of three combined measures for $\mathrm{CO}_{2}$ emission reduction in industry, i.e. fuel switching, electrification, and adoption of Carbon Capture and Storage (CCS) and to simulate plausible scenarios (base scenario and climate ambitious scenario) for curbing emissions in the iron and steel sector in the USA between 2010 and 2050. Results show that when the climate ambitious scenario is applied, the cumulative emissions into the atmosphere $\left(2,158 \mathrm{Mt} \mathrm{CO}_{2}\right)$ are reduced by $40 \%$ in comparison to the base scenario $(3,608 \mathrm{Mt}$ $\mathrm{CO}_{2}$ ). This decarbonization gap between both scenarios intensifies over time; in the year 2050, the $\mathrm{CO}_{2}$ intensity in the climate ambitious scenario is $81 \%$ lower in comparison to the base scenario. The study shows that major contributions to industry decarbonization can come from the further uptake of secondary steel production. Results show also that a carbon tax drives the decarbonization process but is not sufficient on its own. In addition, the uptake of innovative low-carbon breakthrough technologies is necessary. It is concluded that industrial electrification is counterproductive for climate change mitigation, if electricity is not provided by low-carbon sources. Overall, fuel switching, industrial electrification, and CCS adoption as single measures have a limited decarbonization impact, compared to an integrated approach that implements all the measures together providing a much more attractive solution for $\mathrm{CO}_{2}$ mitigation.
\end{abstract}

Keywords: emissions; energy; integrated assessment model; industrial electrification; CCS; industry

\begin{tabular}{lll}
\multicolumn{2}{l}{ Abbreviations } \\
a, b, c & regression constants & \\
BF & Blast Furnace & \\
BOF & Basic Oxygen Furnace & \\
BS & Base Scenario & {$[\mathrm{Mt}]$} \\
C & Capacity & {$[2010 \mathrm{USD} / \mathrm{Mt} /$ year $]$} \\
CAPEX & specific CAPital EXpenditures & \\
CAS & Climate Ambitious Scenario & {$[2010 \mathrm{USD}]$} \\
CCS & Carbon Capture and Storage & {$[\mathrm{Mt}]$} \\
CF & Cash Flow & {$[2010 \mathrm{USD}]$} \\
$\mathrm{D}$ & Demand & \\
DCF & Discounted Cash Flow & \\
DR & Direct Reduction & \\
DRI & Direct Reduced Iron & \\
${ }^{1}$ Present affiliation of Sandro Luh: & \\
Paul Scherrer Institute, Laboratory of Energy Systems Analysis, 5232 Villigen PSI, Switzerland \\
ETH Zurich, Dpt. of Chemistry and Applied Biosciences, Raemistrasse 101, 8092 Zurich, Switzerland
\end{tabular}




$\begin{array}{lll}\text { EAF } & \text { Electric Arc Furnace } & \\ \text { GDP } & \text { Gross Domestic Product } & \\ \text { GDPpc } & \text { Gross Domestic Product per capita } & \\ \text { HFO } & \text { Heavy Fuel Oil } & \\ \text { IAM } & \text { Integrated Assessment Model } & \\ \text { IEA } & \text { International Energy Agency } & \\ \text { HFO } & \text { Heavy Fuel Oil } & \\ \text { ISM } & \text { Industrial Sector Module } & \\ \text { LPG } & \text { Liquefied Petroleum Gas } & \text { [2010 USD] } \\ \text { MCA } & \text { Market Clearing Algorithm } & \text { [2010 USD / Mt] } \\ \text { MUSE } & \text { ModUlar energy system Simulation Environment } & \text { [PJ/Mt] } \\ \text { NPV } & \text { Net Present Value } & \\ \text { OPEX } & \text { specific fixed OPerational EXpenditures, including carbon tax } & \text { [year] } \\ \text { SEC } & \text { Specific Energy Consumption } & {[\mathrm{PJ}]} \\ \text { SR } & \text { Smelt Reduction } & {[\%]} \\ \text { SSP } & \text { Shared Socioeconomic Pathway } & \\ \Delta t & \text { time period } & \\ \text { TFEC } & \text { Total Final Energy Consumption } & \\ \text { UF } & \text { Utilization Factor } & \\ \text { USA } & \text { United States of America } & \end{array}$

\section{Introduction}

Climate change is one of the most pressing issues for global society with large ecological and economic impacts (OECD, 2015a). Given this situation, the Paris Agreement calls for dramatic changes in the energy system to limit the global temperature increase to less than $2^{\circ} \mathrm{C}$ relative to pre-industrial levels (Rogelj et al., 2018; United Nations Framework Convention on Climate Change, 2016)

An extensive shift in the global energy system is necessary and all the energy sectors should find ways to reduce $\mathrm{CO}_{2}$ emissions. The industrial sector accounts for the largest share of global Total Final Energy Consumption (TFEC) among all sectors (37\% in 2015 (IEA, 2017a)). Consequently, the mitigation of industrial $\mathrm{CO}_{2}$ emissions has a crucial role in meeting climate targets (Fais et al., 2016). Given a continuously increasing demand for industrial products, the key for industrial decarbonization is decoupling its production from the produced $\mathrm{CO}_{2}$ emissions (IEA, 2017b). Suitable measures for achieving this include energy and material efficiency strategies, such as adoption of best available technologies and improved scrap collection and reprocessing rates (IEA, 2017b; Rogelj et al., 2018; United Nations Climate Change Secretariat, 2018). Other relevant measures are switching to lower-carbon fuels and feedstocks, such as natural gas as substitution for coal, and future adoption of Carbon Capture and Storage (CCS) in industrial processes (IEA, 2017b; Rogelj et al., 2018). In addition, more recent literature suggests increased industrial electrification as a suitable option for decarbonization (IEA, 2017b; Kempener and Saygin, 2014; Lechtenboehmer et al., 2016; Rogelj et al., 2018). This option has received increasing attention due to the possibility of generating electricity from low-carbon energy sources, such as renewables, nuclear energy, and fossil fuels with integrated CCS (Sugiyama, 2012).

Integrated Assessment Models (IAMs) are important tools, showing potential long-term future pathways based on technological developments and policy decisions (Weyant, 2017). Such modelling methods experience a rapid increase in awareness, as only they allow to assess the combined effects of multidimensional variables regarding climate, technology, economy, and policy (Kriegler et al., 2015b; Weyant, 2017). They model the global energy system by quantifying material commodity production, use of services, consumption of energy commodities and feedstocks, and their corresponding impacts on climate change, typically by greenhouse gas emissions, over time (Edenhofer et al., 2014). IAMs mainly consider representations of natural-, climate-, and human systems (e.g. energy and economic) in order to produce energy and greenhouse gas emission pathways in return (Janetos, 2009).

Currently, there is limited literature about IAMs that are suitably focusing on the industrial sector (Iyer et al., 2015; Wesseling et al., 2017). A model comparison by Edelenbosch et al. (2017) has shown that IAMs struggle to have a good characterization of the industrial sector, due to the complexity of the technological options present. Therefore, focusing on one industrial subsector can bring the advantage of a higher level of technological detail in comparison to models that aggregate multiple industrial subsectors.

This paper aims to fill this gap in the literature by presenting a novel modelling framework, the Industrial Sector Module (ISM), which simulates investment decisions in industry and has been developed as part of a novel IAM, the MUSE model (ModUlar energy system Simulation Environment) (García Kerdan et al., 2019; Giarola et al., 2019). In order to demonstrate the investment decision algorithm behind the ISM and the model capabilities, a case study is proposed to simulate the development of the iron and steel subsector in the USA and to assess a potential pathway for the decarbonization of the sector. USA is the country with the highest Gross Domestic Product (GDP), the second most emitting country worldwide and traditionally one of the major steel producing countries ([dataset] World Steel Association, 2018; IEA, 2017a; The World Bank, 2018a). 
The case study aims to give insights on how fuel switching, CCS, and industrial electrification could pave the way to the decarbonization of iron and steel. While electrification provides decarbonization potentials for many industrial subsectors, the increasing electrification rate of the iron and steel subsector is expected to have a strong future potential for overall $\mathrm{CO}_{2}$ emission mitigation (IEA, 2017c). This is because this subsector produces the most industrial $\mathrm{CO}_{2}$ emissions (2014: 28\%, 2,338Mt CO 2 ) and is moreover expected to experience the strongest increase in electrification rate among the five main industrial subsectors (from 12\% in 2014 to 23\% in 2050 according to the International Energy Agency's (IEA) $2^{\circ} \mathrm{C}$ Scenario) ([dataset] IEA, 2017). Iron and steel production can be divided into three sub-processes: ironmaking including raw material preparation, steelmaking for crude steel production, and steel manufacturing (van Wortswinkel and Nijs, 2010). This work is focusing on ironmaking and crude steelmaking, while excluding steel manufacturing into final products. The overall energy demand of the iron and steel sector is taken into account for calibration to IEA Energy Balances ([dataset] IEA, 2016). Global production of crude steel has continuously increased from 750Mt steel in the 1990's up to 1,808Mt steel in 2018 (World Steel Association, 2019a).

The case study projects scenarios of the USA iron and steel industry and illustrates the potential for increased electrification, fuel switching, and adoption of CCS. The potential for $\mathrm{CO}_{2}$ emission mitigation by means of these three measures were explored by simulating potential developments of the industrial sector between 2010 and 2050. Two different scenarios, Base Scenario (BS) and Climate Ambitious Scenario (CAS), were applied in order to compare different potential future pathways.

The remainder of the paper is organized as follows. First, background information about technologies in the iron and steel industry is given, followed by a description of the methodology and a definition of modelling assumptions and data sources. The USA case study is then presented, followed by concluding remarks.

\section{Background: Steelmaking}

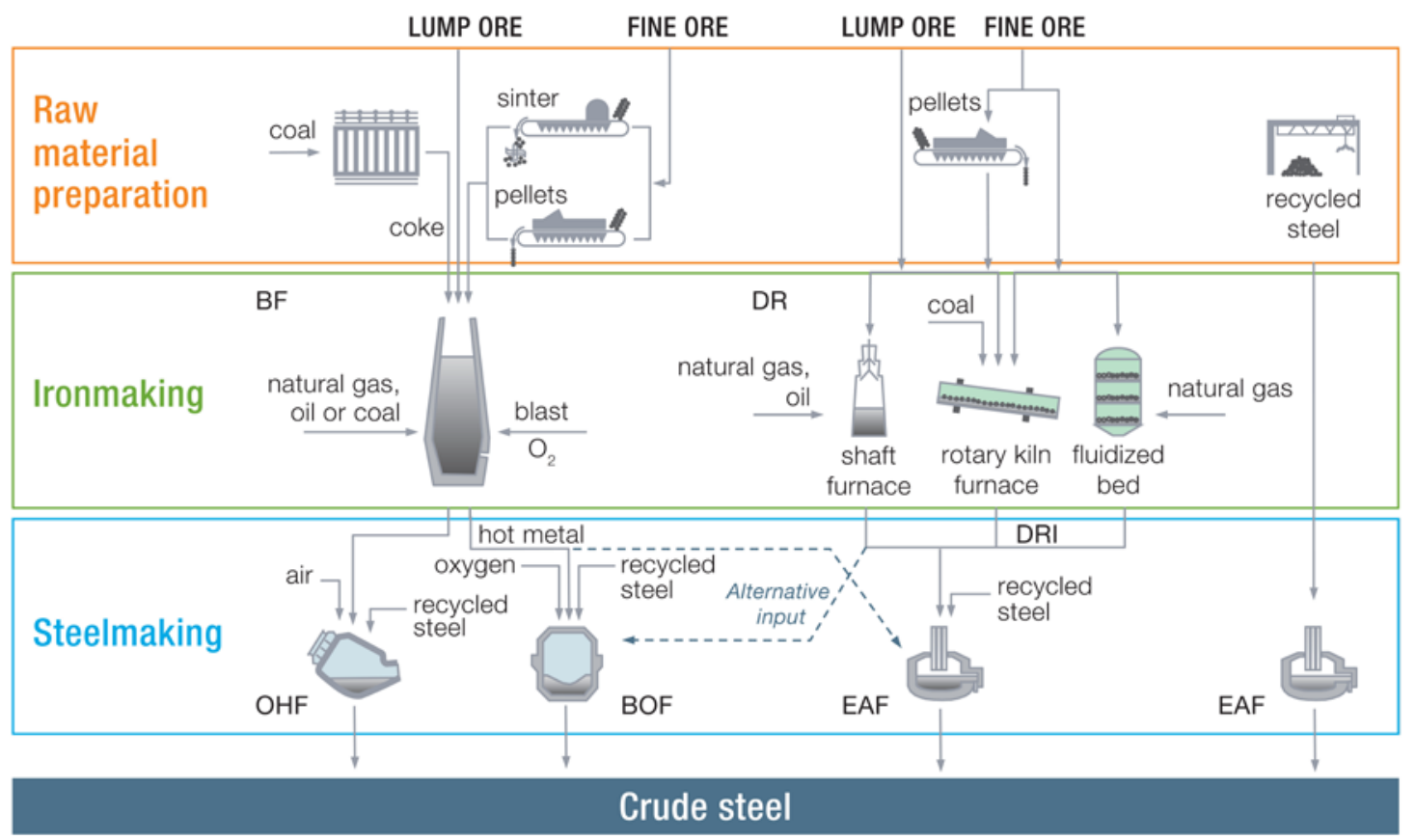

Figure 1. Steelmaking routes from raw materials to crude steel. Reproduced from World Steel Association (2019b) with the permission of The World Steel Association. The single production steps of the primary steelmaking routes BF-OHF, BF-BOF, and DR-EAF and the secondary steelmaking route scrap-EAF are shown.

Figure 1 gives a detailed overview about today's production routes for crude steel. For primary steel production, iron ore is first converted to iron, i.e. hot metal or Direct Reduced Iron (DRI), which is the main feedstock for the following steel production (Yellishetty et al., 2010). Hot metal can be made from iron ore by reduction and subsequent melting of iron oxide in a Blast Furnace (BF) (World Steel Association, 2019c; Worrell et al., 2008). In contrast, DRI is made by Direct Reduction (DR) of iron oxide in a solid state. Smelt Reduction (SR) (not mentioned in Figure 1) is a novel technology that produces iron by reducing and melting iron ore in a hot bath. Subsequently, the produced iron is converted, together with a small share of recycled steel (scrap), to crude primary steel by further reduction in a Basic Oxygen Furnace (BOF) or by being melted in an Electric Arc Furnace (EAF). The combined production routes for primary steel production are BF-BOF, DR-EAF, and SR-BOF (Napp et al., 2014). The BF-OHF (Open Hearth Furnace) technology is outdated and not considered in this work ([dataset] World Steel Association, 2018; World Steel Association, 2016a). Secondary steel can be produced by melting 
steel scrap in an EAF using a strong electric current, referred to as scrap-EAF (see Figure 1) (van Wortswinkel and Nijs, 2010).

The scrap-EAF production route requires only a fourth of the energy consumption of primary production routes, i.e. BF-BOF, DR-EAF, and SR-BOF. However, while the primary steel production routes mainly use iron ore as raw material, the uptake of scrap-EAF is mainly limited by the availability of steel scrap, which is expected to increase globally by $\sim 80 \%$ by 2050 as steel is highly recyclable (Janetos, 2009; McKinsey \& Company, 2018; World Steel Association, 2016b, 2012a). Nonetheless, in ambitious climate change scenarios, the expected increased electrification in the iron and steel sector is mainly based on a shift from primary steel production technologies to the scrap-EAF technology (IEA, 2017b).

Beyond BF-BOF, DR-EAF, SR-BOF, and scrap EAF, several emerging technology options show promising results on lab- and pilot scale for decarbonization and electrification in the long-term future. For ironmaking, direct reduction of iron ore pellets is possible together with hydrogen, which can be produced by electrolysis of water with electricity (SSAB AB, 2016). An innovative technology for steelmaking directly from iron ore is Electrowinning, i.e. the ULCOWIN technology, which produces steel by electrolysis (EUROFER - The European Steel Association, 2013; IEA, 2017b). These technologies could boost electrification in the iron and steel sector in the future, leading to decarbonization if the electricity comes from renewable energy sources. A technology that could lead to further decarbonizing ironmaking are HIsarna blast furnaces, which could replace traditional blast furnaces and do not require the production of coke, sinter, and iron pellets as intermediary products (Tata Steel, 2018; van der Stel et al., 2013). HIsarna blast furnaces are in particular attractive for decarbonization when they are combined with integrated CCS plants, as their off-gases have high $\mathrm{CO}_{2}$ concentrations (IEA, 2017b; Tata Steel, 2018).

Various literature gives an overview about the expected global steel production development. While BF-BOF and DR-EAF accounted for $70.5 \%$ and $6.2 \%$ of global crude steel production in 2014, the novel SR-BOF technology has no market share yet (IEA, 2017c). In ambitious climate change scenarios of the IEA, the SR-BOF technology is expected to penetrate the market in the future (IEA, 2017b). The scrap-EAF technology route accounted for 23.3\% of global crude steel production in 2014 (IEA, 2017c). Despite its advantages against primary steelmaking, this share is declining on a global level since 2000 due to large expansions of BF-BOF capacities in China ([dataset] World Steel Association, 2018; Holloway et al., 2010). Nevertheless, according to the IEA the global share of EAF technologies is expected to increase again in the future, as the steel production in China is predicted to plateau (IEA, 2017b). Further, the production shares of single technologies differentiate strongly among regions ([dataset] World Steel Association, 2018). This comes from differences in domestic scrap availability and the need for large-sized or small-sized capacity expansions (OECD, 2015b). While large-sized capacity expansions can easily be provided from BFs with great volumes, small-sized capacity expansions can also be provided from EAFs (OECD, 2015b).

Today, the global steel market is dominated by China who produce $51 \mathrm{wt} \%$ of the global crude steel (World Steel Association, 2019a). Other significant producers include India (6wt\%), followed by Japan (6wt\%) and the USA (5wt\%) (World Steel Association, 2019a). Main fuels for global steel production in 2014 were coal (41\%), natural gas (36\%), and electricity (21\%) ([dataset] IEA, 2016). Major contributions for future $\mathrm{CO}_{2}$ emission reductions in the iron and steel sector are expected to come from the integration of CCS technologies, a fuel switch from coal to gas, and industrial electrification due to increased use of EAF-technologies (Global CCS Institute, 2015; IEA, 2017b).

\section{Methodology: MUSE Model Framework and Case Study Definition}

The methodology is based on a newly developed simulation modelling framework for the investment decisions in industry, the ISM. The model coded in Python is part of the MUSE model. In this section, an overview of the MUSE IAM will be given, followed by the ISM methodology description.

\subsection{The MUSE model: A novel energy systems model}

This section and the following one report the structure of the MUSE model as described in Giarola et al. (2019).

MUSE simulates energy systems transitions over long time horizons, with a partial equilibrium on the energy system provided by iterative microeconomic supply-demand market clearing for each energy commodity. A commodity refers to either primary energy resources, secondary fuels, or material goods exchanged in the market. The model simulates the whole energy system (i.e. including demand, transformation/conversion, and supply sectors) with a high degree of technical detail, where capital and operating costs as well as environmental performance are modelled. The key distinguishing features of MUSE are: (1) modularity and (2) the enabling of modelling of real consumer, firm and government investment and operational decision-making. This means that each sector of the economy can be modelled in a way that is specifically appropriate for that sector, and that each unique sector approach can still be brought together in the MUSE partial equilibrium to form a view of an overall energy transition.

Model implementations with different geographical scope and purpose can be built within the MUSE framework. MUSE-Global represents the global scale, with a geographical disaggregation into 28 regions and a 
time horizon to 2100. The model recursively calculates an endogenous global carbon price in order to incentivize technology transitions in each sector. It is designed to examine long-term developments of the energy systems in alternative plausible future pathway scenarios. In order to achieve this goal, it quantifies complex relationships within the energy system among technologies, economics, policies, and environment. Starting from a chosen base year for the start of the simulation, where all the technology stocks are modelled to replicate the IEA energy balance for all the energy sectors and countries as aggregated into regions, different future pathway scenarios can be created by varying selected constraints, such as carbon taxes, fuel prices, and adoption of CCS.

The MUSE modelling environment has a modular structure where each sector of the energy system is simulated by an individual module. This modular architecture of MUSE allows flexibility because each module can be run independently or linked with other modules via a Market Clearing Algorithm (MCA) (Figure 2). As well as the modular separation of the energy sectors, the global energy system is also geographically disaggregated into regions, which can also be run independently. Thereby, regional differences, such as existing stocks of technologies and socioeconomic developments, can be considered.

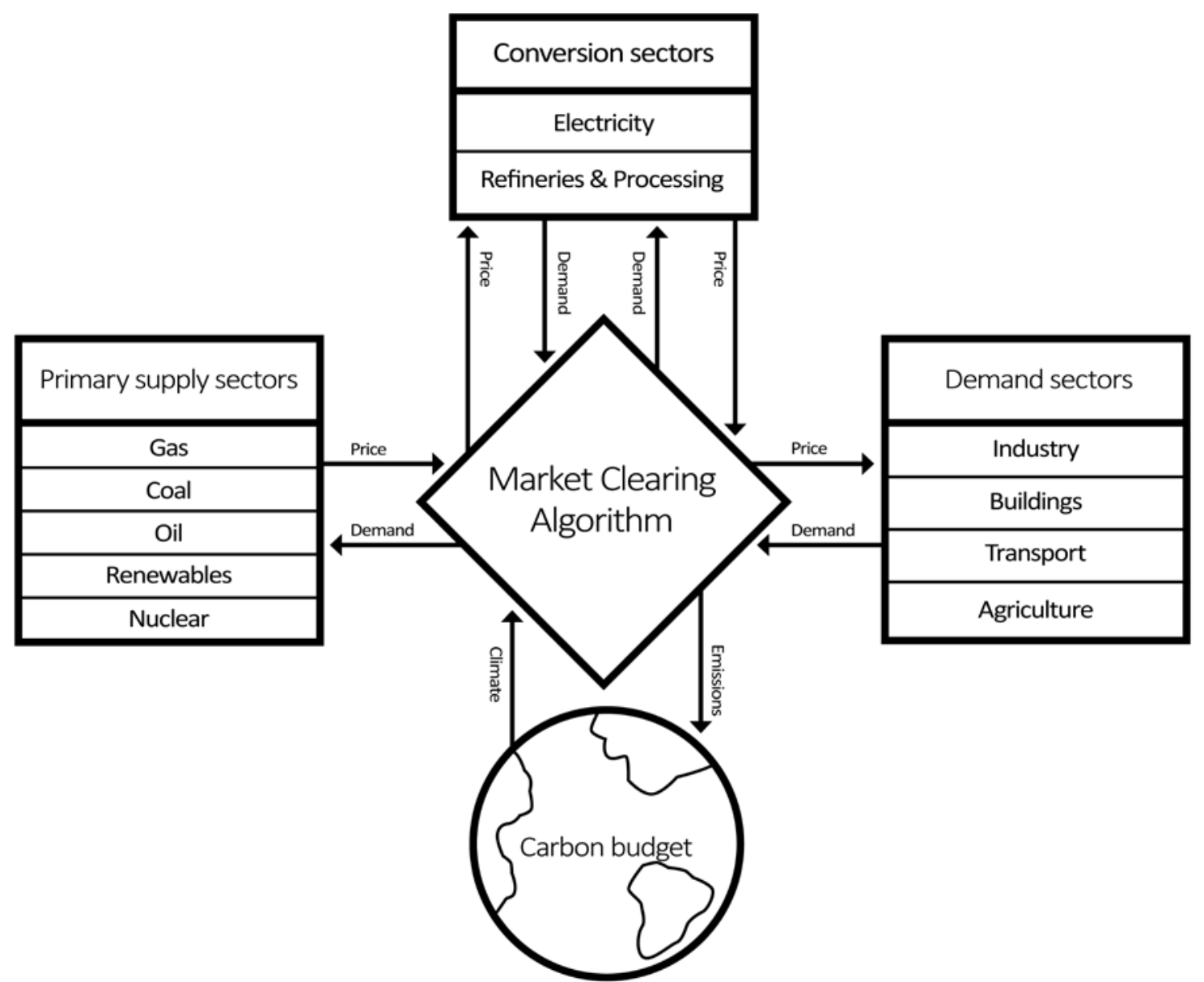

Figure 2. MUSE model architecture. Supply, conversion, and demand of energy interact by means of a Market Clearing Algorithm according to market equilibrium principles and by taking into account a carbon budget.

Commodities in MUSE are separated into energy commodities and material commodities. A limited foresight approach determines demand trajectories of material commodities and future prices of energy commodities, which are known over a rolling time horizon. This limited knowledge of future demand and prices differentiates MUSE from the intertemporal approach of many IAMs. For demand projections of commodities in each energy end-use demand sector module, macroeconomic inputs based on Shared Socioeconomic Pathways (SSPs) are applied (International Institute for Applied Systems Analysis, 2016).

\subsection{The Industrial Sector Module (ISM) of MUSE}

The industrial module is on the demand-side of the MUSE model (see Figure 2). It simulates investment and operation decisions in the five major industrial subsectors, i.e. iron and steel, non-metallic minerals, chemicals and petrochemicals, non-ferrous metals, and pulp and paper. The industrial sector breaks-down into the main five most emitting subsectors, which represents a common approach in IAMs, reflecting the IEA classification (IEA, 2017a; Loulou and Labriet, 2008). The ISM quantifies, for a given future scenario, which industrial technologies are commissioned at a certain point in time. In addition, it quantifies for each point in time Final Energy Consumption 
(FEC) and $\mathrm{CO}_{2}$ emissions produced. This includes captured (by CCS) and non-captured $\mathrm{CO}_{2}$ from fuel combustion and chemical processes.

The energy commodities considered are biomethane, electricity, forest residues, hard coal, Heavy Fuel Oil (HFO), Liquefied Petroleum Gas (LPG), naphtha, and natural gas. Material commodities are manufactured goods provided by the five industrial key subsectors. They are represented in each region by 14 representative material commodities, which have been selected based on their global production and their market share within the corresponding subsector (Table 1). Each technology for the production of these material commodities is characterized in each region by a series of techno-economic parameters (Table 2).

Table 1. MUSE industrial subsectors, material commodities, and production technologies

\begin{tabular}{|c|c|c|}
\hline Industrial subsector & Material commodity & Production technologies \\
\hline \multirow[t]{4}{*}{ Iron and steel } & Steel & BF-BOF \\
\hline & & SR-BOF \\
\hline & & DR-EAF \\
\hline & & Scrap-EAF \\
\hline \multirow[t]{2}{*}{ Non-metallic minerals } & Cement & Dry process \\
\hline & & Wet process \\
\hline \multirow[t]{23}{*}{ Chemicals } & Ammonia & Ammonia from coal \\
\hline & & Ammonia from natural gas \\
\hline & & Ammonia from $\mathrm{HFO}$ \\
\hline & & Ammonia from biomethane \\
\hline & & Ammonia from water electrolysis \\
\hline & Benzene & Aromatic extraction \\
\hline & & Steam cracking \\
\hline & Butadiene & $\mathrm{C}_{4}$ separation \\
\hline & & Steam cracking \\
\hline & Ethylene & Steam cracking \\
\hline & Fertilizers (N, P, K) & $\mathrm{N}$-fertilizers from ammonia \\
\hline & & P-fertilizers from phosphate minerals \\
\hline & & K-fertilizers from potassium minerals \\
\hline & Halogens & Fluorine from $\mathrm{HF}$ \\
\hline & & Bromine by electrolysis \\
\hline & & Iodine from $\mathrm{SO}_{2}$ and nitrate ores \\
\hline & Methanol & Methanol from coal \\
\hline & & Methanol from natural gas \\
\hline & Propylene & Fluid catalytic cracking \\
\hline & & Steam cracking \\
\hline & Toluene & Aromatic extraction \\
\hline & & Toluene production for TDI \\
\hline & Xylenes (isomers) & Aromatic extraction \\
\hline \multirow[t]{2}{*}{ Non-ferrous metals } & Aluminum & Prebaked process \\
\hline & & Soderberg process \\
\hline \multirow[t]{2}{*}{ Pulp and paper } & Pulp and paper & Chemical process \\
\hline & & Mechanical process \\
\hline
\end{tabular}

Table 2. Overview of techno-economic parameters characterizing each technology in each region

\begin{tabular}{|c|c|c|}
\hline Parameter & Unit & Description \\
\hline Input energy consumption & {$[\mathrm{PJ} / \mathrm{Mt}]$} & $\begin{array}{l}\text { Energy required to produce one Mt of output material } \\
\text { commodity }\end{array}$ \\
\hline $\begin{array}{l}\text { Output material } \\
\text { commodities }\end{array}$ & {$[\mathrm{Mt} / \mathrm{Mt}]$} & $\begin{array}{l}\text { Mt of output material commodity per Mt of the } \\
\text { technologies' main output material commodity }\end{array}$ \\
\hline $\mathrm{CO}_{2}$ emissions & [kt/Mt] & $\begin{array}{l}\text { kt of } \mathrm{CO}_{2} \text { emissions per Mt of produced output material } \\
\text { commodity }\end{array}$ \\
\hline $\begin{array}{l}\text { Specific CAPital } \\
\text { EXpenditures (CAPEX) }\end{array}$ & [106 USD/Mt/year] & Costs for investments in new capacity \\
\hline $\begin{array}{l}\text { Specific fixed OPerational } \\
\text { EXpenditures (OPEX) }\end{array}$ & {$\left[10^{6} \mathrm{USD} / \mathrm{Mt}\right]$} & $\begin{array}{l}\text { Costs for operation and maintenance, including carbon } \\
\text { tax }\end{array}$ \\
\hline Initial installed capacity & [Mt] & Capacity installed in the base year \\
\hline
\end{tabular}




$\begin{array}{lll}\begin{array}{l}\text { Maximum capacity } \\ \text { addition per year } \\ \begin{array}{l}\text { Maximum capacity growth } \\ \text { per year }\end{array}\end{array} & {[\mathrm{Mt}]} & \begin{array}{l}\text { Upper boundary for absolute amount of annual capacity } \\ \text { addition } \\ \text { Upper boundary for annual capacity growth in relation to } \\ \text { the already existing capacity } \\ \text { Upper boundary for absolute capacity }\end{array} \\ \begin{array}{l}\text { Technical lifetime } \\ \text { Utilization Factor (UF) }\end{array} & \begin{array}{l}\text { [years] } \\ {[\%]}\end{array} & \begin{array}{l}\text { Operational years of a plant until it will retire. } \\ \text { Ratio of the time in which a technology is operating }\end{array}\end{array}$

Note. For representing energy efficiency improvements over time, such input-parameters are time-dependent. They are defined with separate values in 2010 and 2030, while values are interpolated between such years, and are constant after 2030.

Figure 3 shows how the ISM and MCA interact by iteratively exchanging information in each single time period of the simulation in order to reach a partial equilibrium for each region. The ISM forwards the projected demand of material commodities, their corresponding demand of fuels, and the related $\mathrm{CO}_{2}$ emissions to the MCA. In return, it receives from the MCA defined prices for $\mathrm{CO}_{2}$ emissions, material commodities, and energy commodities. After a partial equilibrium is reached, the ISM generates specific outputs for each time period, such as aggregated capital and operational costs as well as capacity, production, and $\mathrm{CO}_{2}$ emissions of each technology.

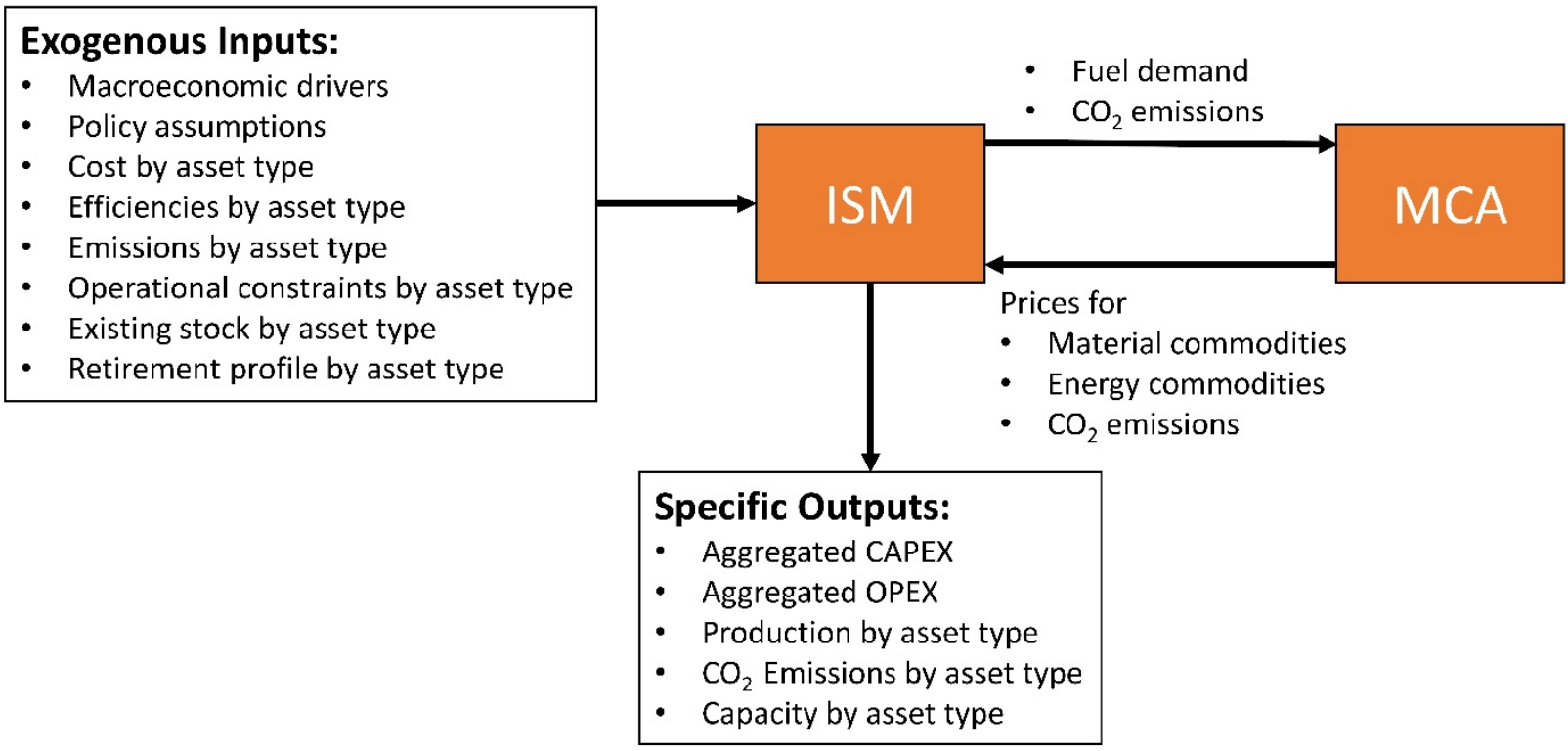

Figure 3. Interactions between the ISM and MCA within MUSE. The exogenous inputs into the ISM, its interactions with the MCA, and the resulting outputs from the ISM are represented.

\subsubsection{Mathematical framework of the ISM}

The block-flow diagram in Figure 4 displays the ISM investment decision workflow. 


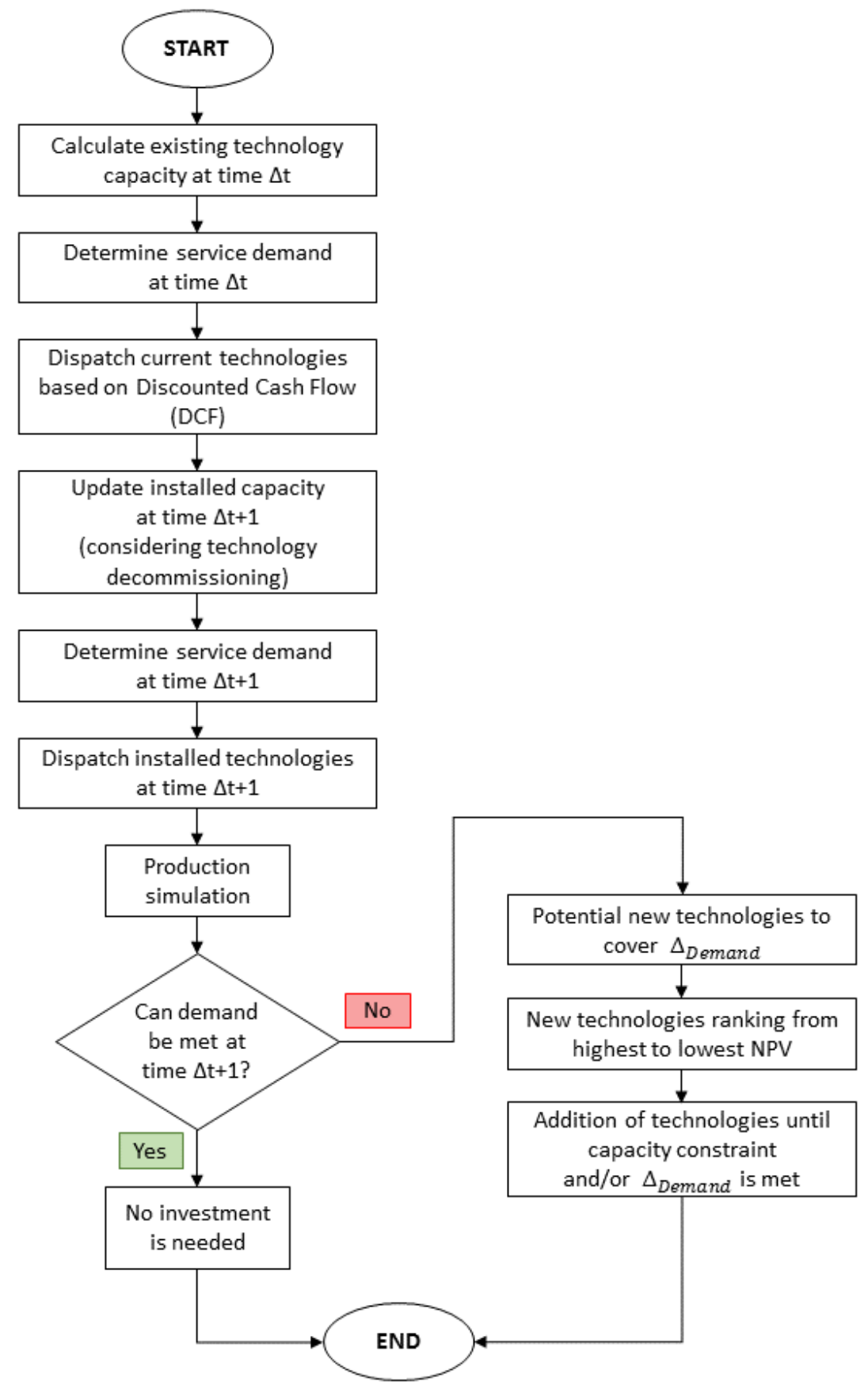

Figure 4. Block-flow diagram of the investment decisions in the ISM

First, the ISM simulates how demand might change for each industrial material commodity, and how existing production capacity for that commodity might retire. The demand of each commodity in each region after 2010 has been correlated to the corresponding Population and the GDP by means of a non-linear inverse equation, developed by van Ruijven et al. (2016). In this equation $D_{\Delta t}$ is the material demand in time period $\Delta t$ (year), GDPpc is the GDP per capita, and $a, b$ and $c$ are constants that have been estimated from regressions of historical data for the past 25 years (United Nations Statistics Division, 2017; van Ruijven et al., 2016):

$D_{\Delta t}=a * \exp \left(\frac{b}{G D P p c}\right) *$ Population $*\left[\frac{c *(\Delta t-2010)^{2}+1}{(\Delta t-2010)^{2}+1}\right]$

The retiring of the existing stock of plants in the ISM is represented by a linear decommissioning profile in order to account for the remaining lifetimes of existing industrial plants. A production gap results from the linear decommissioning profile and from the projected change of each material commodities' demand.

Second, the ISM calculates the new capacity that must be installed in a time period $\Delta t\left(C_{\text {new plants, } \Delta t}\right)$ to close this production gap and consequently meet the demand: 
$C_{\text {new plants }, \Delta t}=\frac{D_{\Delta t}}{U F}-\left(C_{\Delta t-1}-C_{\text {retired }, \Delta t}\right)$

Subsequently, the ISM follows a two-step merit-order approach. In the first step, the available technologies are ranked in order to decide which technologies to bring online until the demand is met. The available technologies are ranked by their Net Present Value (NPV), the investors' key metric used to make investment decisions for new plants, in order to bring online the most profitable technologies. The $N P V$ takes into account the net cash flow in each time period $\Delta t C F_{\Delta t}$, the total initial investment cost $C F_{0}$, and the interest rate $r$ :

$\mathrm{NPV}=\sum_{\Delta t=1}^{T}\left(\frac{C F_{\Delta t}}{(1+r)^{\Delta t}}\right)-C F_{0}$

In order to fulfil the required demand in time period $\Delta t$, the most profitable technology, i.e. the one with the highest $N P V$, is built and made available for production until an upper constraint for new capacity by this technology is met. Then, the ISM moves on to invest into the second most profitable technology, and so on, until the demand can be met from the supply potential. In the second step, when a technology has been installed and is available on the market, the Discounted Cash Flow $(D C F)$ of each technology is calculated in order to select the most profitable existing plants to be operated for production:

$\mathrm{DCF}=\sum_{\Delta t=1}^{T}\left(\frac{C F_{\Delta t}}{(1+r)^{\Delta t}}\right)$

Based on the DCF, the demand for material commodities is first covered by plants with the highest profit, followed by less profitable ones until demand is met. The expenditures within the cash flow of the metrics, NPV and DCF, take into account the CAPEX and OPEX. CAPEX and OPEX are defined for each region and each technology in the model.

The required amount of energy commodities is determined from the mix of technologies that are operated. All technologies have upper growth constraints in order to ensure realistic future market penetration and technology deployment rate. Among three growth constraints for new capacity addition of each technology, i.e. (1) 'maximum annual growth rate' (\%), (2) 'maximum annual capacity addition' (Mt), and (3) 'maximum total capacity in a region' (Mt), the most restrictive one is applied.

\subsection{Relevant Modelling Assumptions and Data Sources}

The ISM is calibrated for 2010 and 2014 in order to match the demand of industrial material commodities, technology shares, and fuel and electricity consumption in the USA, according to multiple databases ([dataset] IEA, 2016; [dataset] World Steel Association, 2018; National Minerals Information Center, 2017; United Nations Environment Programme, 2013). Future demand projections (Equation 1) of each material commodity in each region are based on societal input variables, i.e. population and GDP, which are represented by the SSP2 (International Institute for Applied Systems Analysis, 2016). The SSP2 narrative is selected among five existing SSP narratives, because it describes a societal middle-of-the-road development and is the most commonly used pathway in long-term studies (Fricko et al., 2017). Fuel and electricity price projections for each region are selected from the 450ppm scenario of the IEA (IEA, 2014). Prices within the model are in 2010 USD, and are regionally disaggregated (IEA, 2014; United Nations Statistics Division, 2017). It is important to mention that there is no elasticity of the demand to prices in the model, as MUSE rather evaluates the effect on the technological options to meet a certain service.

The simulation of this study focuses on the industrial sector of the energy system. Therefore, a simplified approach is taken into account for $\mathrm{CO}_{2}$ emissions from power generation. Such emissions are quantified by using selected projections for global specific electricity emissions. These projections are accessed from the IPCC's Assessment Report 5 Scenario Database, Table 3 (International Institute for Applied Systems Analysis, 2015). It is assumed that the reported $\mathrm{CO}_{2}$ emissions from electricity generation in each scenario take already into account the potential implementation of CCS in the power sector and do therefore account for the amount of emissions that are finally emitted to the atmosphere. This study does not include international trade of material commodities, however the commodity demand is estimated taking into account both national and foreign demand.

Table 3. Global specific $\mathrm{CO}_{2}$ emissions from electricity generation (International Institute for Applied Systems Analysis, 2015)

\begin{tabular}{llllllll}
\hline Model & Scenario & Unit & 2010 & 2020 & 2030 & 2040 & 2050 \\
\hline GCAM 3.1 & LIMITS-450 & kt CO $/$ GWh & 0.54 & 0.49 & 0.38 & 0.18 & 0.04
\end{tabular}




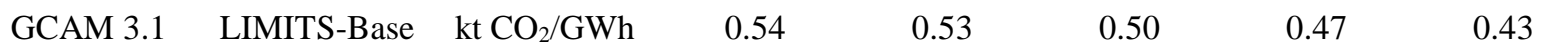

Note. The reported values are calculated from the projected $\mathrm{CO}_{2}$ emissions from electricity generation and the projected secondary energy from electricity in each scenario. The LIMITS-Base scenario is a baseline scenario without specified longterm target. The LIMITS-450 scenario limits the $\mathrm{CO}_{2}$ concentration in the atmosphere to 450ppm in the long-term, which is in line with the Paris Agreement (United Nations Framework Convention on Climate Change, 2016).

The Specific Energy Consumption (SEC) and performance of each technology are calibrated for 2010 and 2014, derived from a set of sources, and relates to final energy consumption values (IEA, 2009, 2017b; IEA Energy Technology Systems Analysis Program, 2017; Worrell et al., 2008). Technologies with integrated CCS are modelled with an efficiency penalty of $12 \%$, and a $\mathrm{CO}_{2}$ capture rate of $90 \%$ (IEA, 2017b; IEA Energy Technology Systems Analysis Program, 2010; Working Group III of the IPCC, 2005). For plants with CCS, the relative additional costs in comparison to the same plants without CCS are assumed to decrease over time: CAPEX and OPEX of plants with CCS are in 2010 48\% higher, and from 2030 onwards 32\% higher than the same plants without CCS (IEA Energy Technology Systems Analysis Program, 2010). An average UF of industrial capacity equal to $90 \%$ was assumed to include a typical number of shutdowns for the planned maintenance of the plants in a year. Technology retrofitting is currently not considered in the model, but any new investment should occur to replace the decommissioned stock when it reaches the end of its lifetime.

The ISM represents the iron and steel sector with the four production routes BF-BOF, SR-BOF, DR-EAF, and scrap-EAF (Table 1). Other emerging technologies for ironmaking and steelmaking (i.e. the use of hydrogen as a reducing agent, Electrowinning, HIsarna blast furnaces) are not yet at commercial stage (EUROFER - The European Steel Association, 2013; IEA, 2017b). This makes it difficult to assume their future efficiencies and costs. Due to the uncertainties resulting from this, such technologies were not considered for this work.

A list of assumptions comparing the techno-economic input data of the four considered steel production routes is presented in the supplementary material (Table A.1). Table A.2 provides the main assumptions for the fuel input data to the ISM.

\subsection{Case Study}

The selected case study covers iron and steel production in the USA for the time frame 2010-2050, disaggregated into time slices for every 5 years. Different scenarios were defined to perform an analysis related to the impact of selected key variables.

\subsubsection{Status Quo in the USA: high steel production by the lower-energy scrap-EAF route}

The USA is a developed region with an annual GDP growth of 2\% since 2010 (The World Bank, 2018b). Currently, there is no nationwide regulation for $\mathrm{CO}_{2}$ pricing in place. The apparent steel use accounted for $122 \mathrm{Mt}$ steel in 2014 ([dataset] World Steel Association, 2018; World Steel Association, 2012b).

Historically, the steel production share of the BF-BOF route peaked at $62 \mathrm{wt} \%$ (1992), followed by a continuous decrease, which was offset by an increasing share of the EAF-routes over time ([dataset] World Steel Association, 2018). In 2014, a base year of the ISM, the secondary steel production by scrap-EAF took over the main market share (52wt\%) ([dataset] World Steel Association, 2018). In the same year, the primary production routes BF-BOF (37wt\%) and DR-EAF (11wt\%) accounted for the residual steel supply ([dataset] World Steel Association, 2018). Due to the low energy-intensity of scrap-EAF in relation to primary steel production routes, the SEC was $~ 7 \mathrm{PJ} / \mathrm{Mt}$ crude steel in recent years - low in comparison to international values ([dataset] IEA, 2016; [dataset] World Steel Association, 2018).

The OECD (OECD, 2015b) expects a rising share of EAFs in the future due to many recent investments in DR-EAF production routes. These investments are made as the shale-gas boom in the USA in recent years has lowered the cost of natural gas, which is typically used to fire DR plants (OECD, 2015b). Additionally, a further uptake of the scrap-EAF production route is expected to contribute to the increasing EAF-share (OECD, 2015b). This comes from an increasing availability of domestic scrap, predicted to grow annually by $1 \%$ between 2010 and 2050 on average (World Steel Association, 2017, 2016b).

\subsubsection{Scenario Definition}

Two different future pathways (scenarios) were simulated in order to perform an analysis for the impacts of a carbon tax and emissions from electricity generation. For this, a Climate Ambitious Scenario (CAS), with carbon policies in place, is compared with the reference from a Base Scenario (BS) where no policy action is required. Due to the absence of policy implications, the BS could be seen as rather extreme, while the CAS is in-line with the 450ppm climate target that was agreed on as minimum goal in the Paris Agreement (United Nations Framework Convention on Climate Change, 2016).

In the Base Scenario (BS) (Table 4), no carbon tax was included and the $\mathrm{CO}_{2}$ emissions from electricity generation were following the 'GCAM 3.1 LIMITS-Base'-scenario (Table 3), which assumes that no particular 
efforts are made to decarbonize the electricity generation over time (International Institute for Applied Systems Analysis, 2015).

In the Climate Ambitious Scenario (CAS) (Table 4), a carbon tax was adopted that represents the average value of the '450ppm Full Technology Portfolio'-scenarios of the IPCC Fifth Assessment Report (Table 5) (Budinis et al., 2018; International Institute for Applied Systems Analysis, 2015). In-line with the aim of the carbon tax to limit the $\mathrm{CO}_{2}$ concentration in the atmosphere to no more than 450ppm, the CAS further assumed the electricity generation emission profile 'GCAM 3.1 LIMITS-450' (Table 3), following this aim by high efforts towards decarbonized electricity generation (International Institute for Applied Systems Analysis, 2015).

The earlier described limited steel scrap availability was considered in both scenarios by setting stricter growth constraints for new capacity addition of the scrap-EAF production route (maximum annual growth rate: 1\%) in comparison to other production routes (3\%).

Table 4. Scenario overview

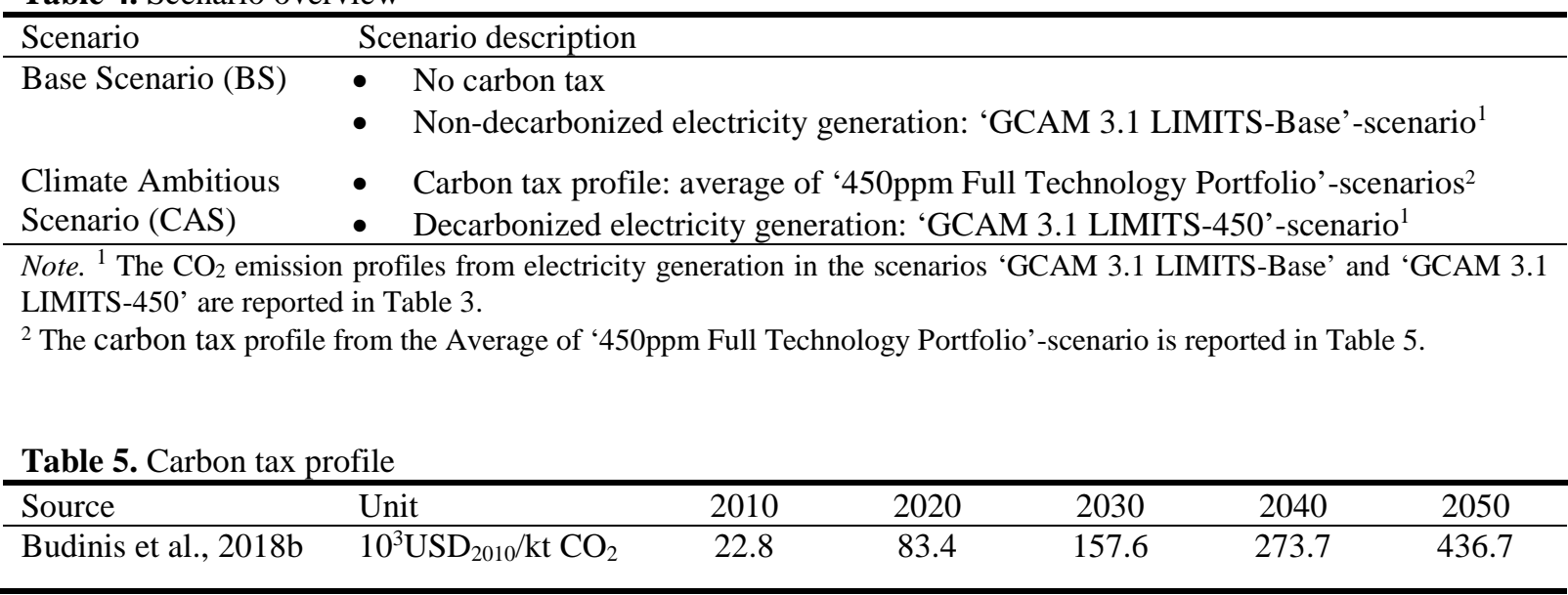

\section{Results and Discussion}

\subsection{Industrial Sector Faces Increasing Demand}

The projected demand for industrial material commodities in the USA is reported in Figure 5. The projected demand is invariant across both scenarios, as it follows the exogenously given factors population and GDP from the SSP2 narrative, which is not sensitive to prices.

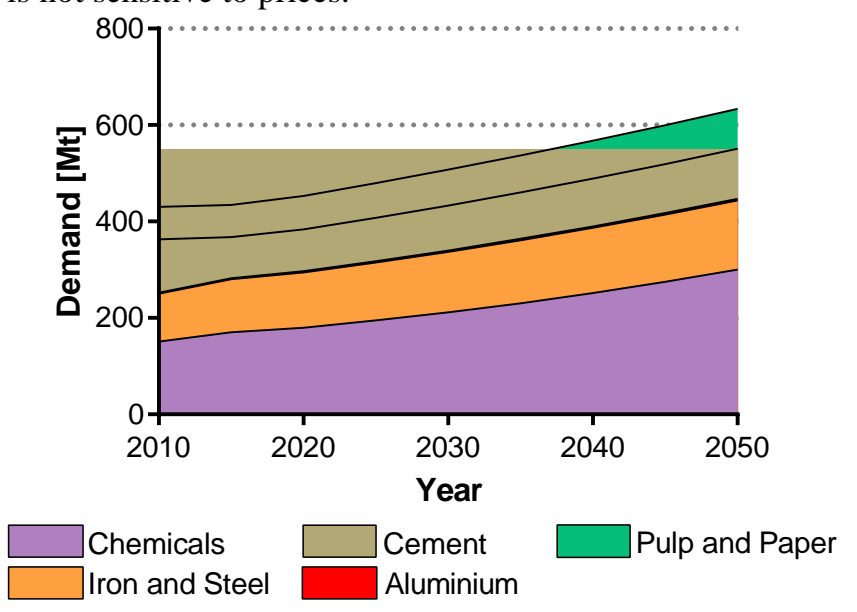

Figure 5. Demand projections for material commodities until the year 2050 in the USA.

The demand for industrial goods increases by 47\% between 2010 (420Mt) and 2050 (634Mt), resulting mainly from increasing demand for chemicals (+98\%) and iron and steel (+45\%). The market share of chemicals increases from 35\% (2010) to 47\% (2050), while the share of iron and steel fluctuates between 23\% and 25\% between 2010 and 2050.

\subsection{Results for Steel Production in the USA: effects of carbon tax and decarbonized electricity generation}

\subsubsection{Production routes}

Figure 6 reports that the steel supply required to cover the demand increases from 99Mt (2010) to 144Mt (2050). In the BS (Figure 6a), steel is in the long-term mainly supplied by the primary BF-BOF production route 
(2010: 38\%, 2050: 37\%) and the secondary scrap-EAF production route (2010: 52\%, 2050: 61\%). The DR-EAF production route is less economic and phases out by 2040. In the CAS (Figure 6b), the investment decision of investors change, as both EAF production routes become increasingly favored in comparison to the supply by BFBOF (2010: 38\%, 2050: 16\%). The steel supply from DR-EAF increases between 2010 and 2050 by a factor of 2.5 (2010: 9Mt steel, 2050: 22Mt steel), while the supply from scrap-EAF increases by almost a factor of two (2010: 52Mt steel, 2050: 97Mt steel).

The results for the production routes demonstrate that the carbon tax clears the way for an uptake of DR-EAF and scrap-EAF.

a)

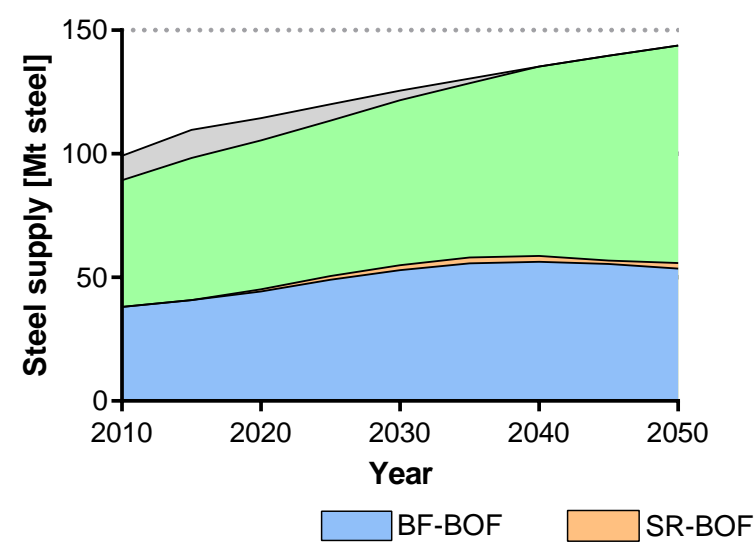

b)

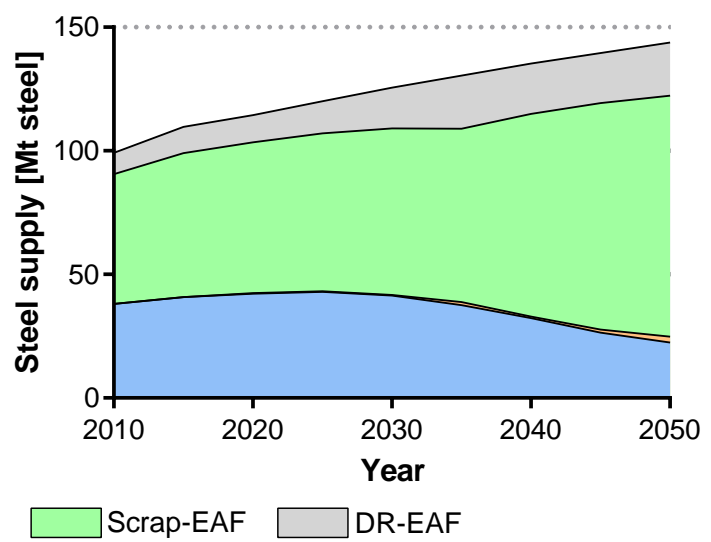

Figure 6. Steel supply by production route in the USA. Projections of steel supply are shown between 2010 and 2050 for the a) BS and b) CAS.

\subsubsection{Fuel shares}

Figure 7a shows that in 2010 mainly natural gas (40\%), coal (37\%), and electricity (22\%) are used in the iron and steel sector. In the BS (Figure 7b), coal mainly offsets natural gas by increasing its share by $26 \%$ between 2010 and 2050. The SEC increases over time from 7.1PJ/Mt steel (2010) to 7.7PJ/Mt steel (2050). In the CAS (Figure 7c), the opposite fuel share development is observed in comparison to the BS: the CAS shows by 2050 that mainly electricity (37\%) and natural gas (47\%) increase in fuel share, while the share of coal is diminished (9\%). The SEC decreases in the CAS from 7.1PJ/Mt steel in 2010 to 5.4PJ/Mt steel (2050).

The results for the fuel shares show that coal is the fuel of choice for investors when no carbon tax is in place, while investors are pushed to natural gas and electrification, if the carbon tax is adopted. In addition, in the CAS the uptake of electricity and the decrease of SEC reflect the strong uptake of the scrap-EAF production route.

a) 2010

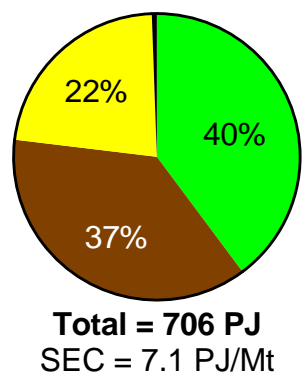

b) $\quad 2050$ (BS)

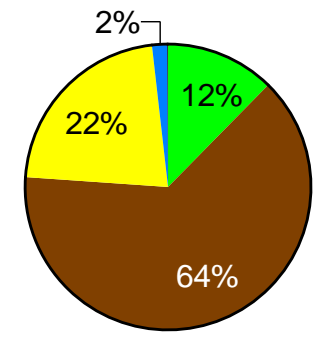

Total $=1,108 \mathrm{PJ}$ SEC $=7.7 \mathrm{PJ} / \mathrm{Mt}$

$\square$ Natural Gas

Biomethane

c) 2050 (CAS)

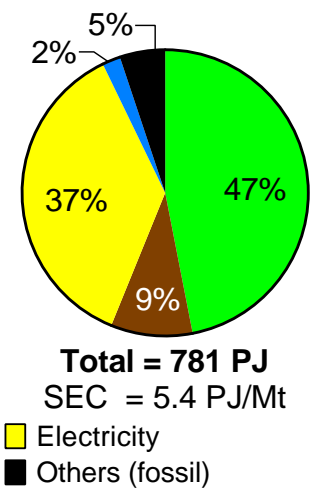

Figure 7. Fuel shares for iron and steel production in the USA. Historic fuel shares are shown for a) 2010. For 2050, the fuel shares are shown for the b) BS and c) CAS. 'Others (bio)' includes forest residues, while 'Others (fossil)' includes HFO, LPG, and naphtha.

\subsection{3. $\mathrm{CO}_{2}$ emissions}

Figure 8 reports for 2010 the production of $72,000 \mathrm{kt} \mathrm{CO}$, of which $33 \%$ come from electricity generation and $67 \%$ from fuel combustion and chemical processes. The BS shows continuously increasing overall and specific produced $\mathrm{CO}_{2}$ emissions over time (2010: 72,000kt CO 2 , 726kt CO $2 / \mathrm{Mt}$ steel; 2050: 115,000kt CO $2,802 \mathrm{kt} \mathrm{CO} / \mathrm{Mt}_{2}$ steel). In particular, increasing $\mathrm{CO}_{2}$ emissions from fuel combustion and chemical processes account for the major increase of overall $\mathrm{CO}_{2}$ emissions in the BS. Furthermore, in the BS no investments take place for technologies with integrated CCS, because no $\mathrm{CO}_{2}$ is captured over time. In comparison, in the CAS the overall produced $\mathrm{CO}_{2}$ emissions have almost halved between 2010 and 2050 (40,000kt $\left.\mathrm{CO}_{2}\right)$, despite the increased steel supply. 
Moreover, 44\% of the emissions produced in 2050 are captured by CCS, resulting in a reduction of the emitted $\mathrm{CO}_{2}$ emissions by $70 \%$ between 2010 and 2050. In 2050, the emitted $\mathrm{CO}_{2}$ emissions of the CAS are reduced by $81 \%$ in comparison to the BS.

The results for the $\mathrm{CO}_{2}$ emissions demonstrate that the carbon tax and decarbonized electricity generation result in significant $\mathrm{CO}_{2}$ emission reduction.

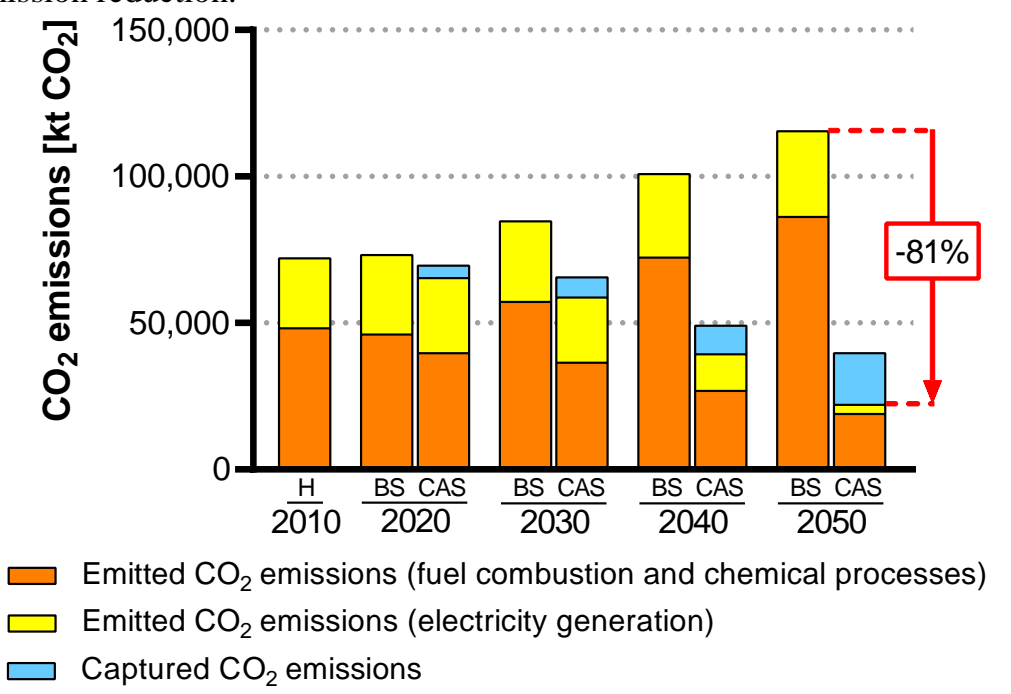

Figure 8. $\mathrm{CO}_{2}$ emissions from iron and steel production in the USA. The overall $\mathrm{CO}_{2}$ emissions are illustrated for each decade (2010 to 2050) of both scenarios (BS and CAS). The $\mathrm{CO}_{2}$ emissions are separated into emitted and captured $\mathrm{CO}_{2}$ from fuel combustion and chemical processes (orange and blue), and into emitted $\mathrm{CO}_{2}$ from electricity generation (yellow).

\subsection{Discussion}

4.3.1. Overall decarbonization potential: adoption of multiple measures is critical to reach $2^{\circ} \mathrm{C}$ climate target

Each single decarbonization measure - electrification, fuel switching, and CCS - was found to have a limited impact for $\mathrm{CO}_{2}$ emission mitigation when implemented on its own. An integrated approach including all these measures created a higher potential for climate change mitigation by $\mathrm{CO}_{2}$ reductions. A carbon tax makes $\mathrm{CO}_{2}$ reduction by all three measures effective. Decarbonization of the power sector is crucial to make increased industrial electrification not becoming a counterproductive measure for overall $\mathrm{CO}_{2}$ emission reduction.

The steel supply needed to cover the demand reflects the socioeconomic future development, which are based on the SSP2 narrative. In the USA, population and GDP are expected to increase steadily, resulting in a steady increase of steel demand (Figure 6).

Table 6. Cumulative emitted $\mathrm{CO}_{2}$ into the atmosphere for iron and steel production (2010-2050).

\begin{tabular}{lcc}
\hline Region & Base Scenario (BS) & Climate Ambitious Scenario (CAS) \\
\hline USA & $3,608 \mathrm{Mt} \mathrm{CO}_{2}$ & $2,158 \mathrm{Mt} \mathrm{CO}_{2}(-40 \%)$ \\
\hline
\end{tabular}

Note. The percentage value in brackets accounts for the change in relation to the BS.

Cumulatively, 5,105Mt of steel are produced between 2010 and 2050. The cumulative emitted $\mathrm{CO}_{2}$ into the atmosphere between 2010 and 2050 in both scenarios reveals a reduction by $40 \%\left(1,450 \mathrm{Mt} \mathrm{CO}_{2}\right)$ when the CAS is applied (Table 6). This relates to an emission gap of $284 \mathrm{kt} \mathrm{CO}_{2}$ per Mt of steel. According to Figure 8, the decarbonization potential in the CAS intensifies over time in comparison to the BS. While in 2020 the emitted $\mathrm{CO}_{2}$ in the CAS is $11 \%$ lower in comparison to the BS, this value increases to $81 \%$ in 2050 . In relation to the emitted $\mathrm{CO}_{2}$ in 2010, the specific emissions in the BS increase until 2050 by $10 \%$ (2010: 726kt $\mathrm{CO}_{2} / \mathrm{Mt}$ steel; BS, 2050: 802kt $\mathrm{CO}_{2} / \mathrm{Mt}$ steel). In comparison, the specific emitted $\mathrm{CO}_{2}$ in the $\mathrm{CAS}$ decreases during this time by $79 \%$ to $154 \mathrm{kt} \mathrm{CO}_{2} / \mathrm{Mt}$ steel, due to investments in more efficient technologies and those with applied CCS, fuel switching, and electrification.

In absolute values, the emitted $\mathrm{CO}_{2}$ increases between 2010 and 2050 in the BS by $60 \%$, while it decreases in the CAS by $70 \%$. However, this reduction in the CAS is still falling behind the target of the first nationally determined contribution submission of the USA for an economy-wide greenhouse gas emission reduction of $80 \%$ or more by 2050 (United States of America, 2015). Consequently, even stronger $\mathrm{CO}_{2}$ emission reductions should be reached, or other sectors need to decarbonize with an accordingly higher share. However, emerging breakthrough technologies, which were not considered in this case study due to their early stage of development, could lead to further decarbonization in the long-term future (see section 2). 
As outlined in section 3.4.1, the OECD (2015b) expects increasing shares of EAF production routes due to investments in DR-EAF and scrap-EAF technologies. This work shows that such developments can be achieved when a carbon tax is in place that is in-line with a $2^{\circ} \mathrm{C}$ climate target. While the scrap-EAF production route experiences an increasing market share with and without economic incentives, the DR-EAF production route is not economically competitive without a carbon tax. Despite the shale-gas boom in the USA, the latter production route requires an economic incentive, such as a carbon tax, to achieve the expected increasing market share (OECD, 2015b).

It should be considered that the results are sensitive to the assumed technical lifetimes of the plants. In reality, plants with high-carbon intense capacity might retire earlier in a low-carbon future. However, for this work it was assumed that such technical lifetimes are identical for both scenarios. With this, the differences between both scenarios can be kept simple, while allowing a good understanding for the underlying reasons that result in in the induced changes of the results. In general, an earlier retirement of high-carbon intense plants in a low-carbon future would lead to a further accelerated transition towards electrification, fuel switching, and CCS adoption, while showing the same conceptual nature of the found results (and vice versa).

The chosen scenarios, BS and CAS, show a broad range of potential future pathways. While the BS implies no policy implications, and the CAS is in-line with a maximum temperature increase of $2^{\circ} \mathrm{C}$ relative to pre-industrial levels, the reality will probably lie somewhere in between of such scenarios. These scenarios have been chosen for the primarily purpose of showing the capabilities of the model to simulate the investment decision in the iron and steel sector. However, it is worth pointing out that these are scenarios to represent potential futures under specific circumstances, but they are not meant to be forecasts.

Overall, the results show that a carbon tax in combination with continuously decarbonized electricity generation is crucial aspects for reaching reach the $2{ }^{\circ} \mathrm{C}$ climate target, which would be in line with the Paris Agreement (United Nations Framework Convention on Climate Change, 2016). Further decarbonization, beyond what was demonstrated in the CAS, should be achieved by emerging breakthrough technologies, improved scrap collection and processing systems leading to increased secondary steel production, and efficiency improvements.

It has been quantified how the production routes (Figure 6), fuel shares (Figure 7), and $\mathrm{CO}_{2}$ emissions (Figure 8) change between both scenarios. From this, inferences can be drawn on the potential of each of the three decarbonization measures, which are discussed in the following.

\subsubsection{Role of electrification}

Increased electrification is strongly linked to an uptake of the EAF production routes, i.e. DR-EAF and scrapEAF. Especially the latter one plays a substantial role for increased electrification, because its electrification rate is approximately one order of magnitude higher than the electrification rate of each primary steel production route. Therefore, production by scrap-EAF results in decreasing emissions from fuel combustion and chemical processes but in increasing emissions from electricity generation due to higher electricity demand. Consequently, when the power sector is not decarbonized, increased electrification becomes counterproductive for climate change mitigation. Therefore, the decarbonization of the power sector is crucial to make increased electrification an effective measure for overall $\mathrm{CO}_{2}$ emission mitigation (Figure 8).

The main limiting factor for an accelerated uptake of the scrap-EAF steel production route in the USA is scrap availability (Figure 6). To overcome this, the amount of available steel scrap must be increased by improving steel recycling rates, and decreasing scrap exports towards or increasing scrap imports from other regions (Fenton, 2018). However, the USA already has a high steel collection and recycling rate of 81\% (in 2014) (Fenton, 2018; Holloway et al., 2010). Yet other countries such as China, by far the largest steel producing country, have scrap collection and processing systems that are more limited (Holloway et al., 2010).

In summary, this case study shows increasing electrification mainly coming from a technology shift towards EAF technologies, in particular the scrap-EAF production route. While investors favor this production route already under current conditions, the limiting factor is scrap availability, which can be overcome by improved scrap recycling rates and reduced scrap exports. Further electrification could be achieved by an uptake of technologies that use electricity for electrolysis, but are currently still on lab-/pilot-scale and have therefore not been considered in the case study. In addition, decarbonized electricity generation is pivotal in order to make increased electrification an effective measure for $\mathrm{CO}_{2}$ emission reduction.

\subsubsection{Fuel switching}

A carbon tax is pivotal to push investors away from coal towards less emission-intensive fuels, like natural gas (Figure 7). While the share of coal increases over time without a carbon tax (BS), the opposite happens when a sufficient carbon tax is in place (CAS). For biomethane, in both scenarios only a small market share is reached. In the BS, biomethane is less favorable than coal, as it is the more expensive fuel. In the CAS, investors favor natural gas over biomethane, as the adopted carbon tax results in a higher price for the latter one

To conclude, a carbon tax is crucial to reduce the specific $\mathrm{CO}_{2}$ emissions by fuel switching. 


\subsubsection{CCS goes beyond other decarbonization measures and is pivotal in reducing the $\mathrm{CO}_{2}$ currently emitted into the atmosphere}

This work proves that commercial incentives or strong policy support are needed for implementing CCS in industrial facilities (Global CCS Institute, 2016). This is, because an economic barrier must be overcome, e.g. by a carbon tax, to clear the way for market penetration of CCS technologies over time (Figure 8, CAS). The high amount of $\mathrm{CO}_{2}$ resulting from fuel combustion and chemical processes in steel production (Figure 8) makes the role of CCS crucial to reduce $\mathrm{CO}_{2}$ emissions.

With the carbon tax in place (CAS), technologies with integrated CCS produce $28 \%$ of the overall produced steel in 2050. This leads to $48 \%$ captured $\mathrm{CO}_{2}$ emissions from fuel combustion and chemical processes. This shows that CCS is most likely to be applied to production technologies accounting for high specific $\mathrm{CO}_{2}$ emissions.

In summary, even though overall $\mathrm{CO}_{2}$ emissions are decreased by increased industrial electrification and fuel switching when a carbon tax is in place, the use of CCS is pivotal to reduce the emitted $\mathrm{CO}_{2}$ from fuel combustion and chemical processes by nearly $50 \%$ in 2050. A potential future uptake of HIsarna blast furnaces, which were not considered in this case study, could provide additional potentials for capturing $\mathrm{CO}_{2}$ emissions due to the attractiveness for integrated CCS plants.

\subsubsection{Assumptions and Limitations}

The ISM was originally developed as a global industrial sector model. In this paper, the focus is rather on explaining the methodology of the investment decisions, and, therefore the model has been adapted to focus on a one-region case study. This implies that a few considerations are due in relation to the extent to which the conclusions obtained from the case study could be considered general. In particular, in order to adapt a global model to a single region description, one of the major assumptions relate to the modelling of international trade. In the model, the projected demand used as a driver for the investment is the domestic production of commodities, which considers that trade has been assumed fixed over time. The international trade is subjected to a complex treaty framework. Within this framework, the introduction of a carbon policy could change the projected demand when trade is included particularly in presence of asymmetric carbon policies among the countries. The carbon leakage effects are excluded from the analysis made in this paper.

The modelling approach used in the ISM is based on modelling investment decisions in new technologies when the existing ones retire at the end of their lifetime. The decisions about which technologies to invest in is based on a merit order approach which is dynamically calculated in the model using a rich detail of engineering cost and environmental performance of each single technology (as shown in Table A.1 and Table A.2). However, the model does not envisage technology retrofitting or an early retirement of the asset before the lifetime. This means that innovation is modelled as a new investment once an asset has reached the end of its lifetime. The authors acknowledge this as a limitation of the study, which makes the modelling approach different from the way investments are realized in the real world. However, it is worth emphasizing that it represents quite a conservative approach to model the uptake of novel technologies in a sector, such as the industrial one, where investments are capital intensive and have long lifetime. The long plant lifetime is crucial in decarbonization scenarios where the timing to curb emissions is very tight in order to avoid temperature increase beyond $2^{\circ} \mathrm{C}$ above pre-industrial times.

The presented results are sensitive to the reported assumptions on cost metrics, such as fuel prices (Table A.2), capital expenditures (Table A.1), operation- and maintenance expenditures (Table A.1), and carbon taxes (Table 4). It is acknowledged that price variations can result in different simulation outcomes. While this work focusses on presenting the methodological framework behind the ISM in the MUSE model, a detailed analysis about the cost metrics was outside the scope. Future work should build on the foundations laid in this work by addressing such aspects in more detail in order to create highly robust model outcomes.

The demand of commodities is modelled as a functional relation of exogenous GDP and population without adjustments due to commodity price elasticities. Although this represents a simplification compared to the commodity market, it depends on the nature of the MUSE model to perform a partial equilibrium approach just on energy commodities, such as fuel and electricity. Other IAMs include a price feedback on the service demand assuming historical values of demand elasticities to prices (The Joint Global Change Research Institute, 2019).

The ISM as presented in this work does not include the effects of climate change on the economic growth. Some IAMs have attempted to model this by using damage functions (RFF-CMCC European Institute on Economics and the Environment, 2019). Still there is not a wide consensus about how the issue should be addressed and it represents an important issue of IAMs.

The ISM can capture policy interventions such as technology-based subsidies. Also, in order to model decarbonization pathways, the model can include carbon as well as emissions tax. Uncertainty in the policy framework and the lack of consistent regulation particular in certain matters such as climate change are difficult to capture in ISM, as it is in the general integrated modelling assessment community (Kriegler et al., 2015a). In this perspective, the role of IAMs is to provide a range of plausible futures to help the decision-making process, making sure that transparency in the methodology and the data is guaranteed. 


\section{Conclusion}

This work has shown the methodology behind the investment decision algorithm in the ISM of MUSE. It has been presented how the ISM can be effectively applied. This lays the foundation for presenting in-depth analyses for the industrial sector in the future.

Industrial decarbonization, via decoupling industrial production from its $\mathrm{CO}_{2}$ emissions, is crucial to mitigate climate change. Multiple measures, such as industrial electrification, fuel switching, and CCS, can be adopted to reach this goal. This paper shows the market penetration of different technologies, with and without a carbon tax, and analyzes the potential for the three measures to decarbonize the industrial sector. For this, the ISM of the MUSE model has been applied on a specific case study analyzing the production of iron and steel in the USA.

In order to make increased electrification an effective measure, it is pivotal to decarbonize the power sector. Increased electrification by means of a shift to EAF technologies in the USA is mainly limited by scrap availability. Therefore, scrap recycling rates should be maximized. While there is no direct economic barrier for the uptake of EAF technologies, an economic incentive, such as a carbon tax, is necessary for shifting the fuel supply away from coal towards lower-carbon fuels. Moreover, a carbon tax drives investors to invest in plants with integrated CCS, especially for $\mathrm{CO}_{2}$ intensive technologies. The deployment of CCS goes beyond the emission reductions from fuel switching and electrification, and is pivotal for decreasing the amount of $\mathrm{CO}_{2}$ that reaches the atmosphere. In addition, this work shows that CCS is not implemented in industrial facilities without strong policy support or commercial incentives.

Each of the three analyzed measures has limited impact on reaching ambitious climate goals. An integrated approach, implementing of all three measures, is needed for sufficient abatement for the sector to play its part in climate change mitigation. For this, a carbon tax is found to result not only in the use of more efficient technologies, and fuels with lower $\mathrm{CO}_{2}$ emissions, but moreover in the uptake of CCS technologies within the iron and steel production chain. In addition, other decarbonization measures, such as improved energy and material efficiency, should be implemented in order to create a broader set of measures. Moreover, the uptake of innovative low-carbon breakthrough technologies is crucial for reaching deep decarbonization. Overall, while the case study of this work shows that a carbon tax and decarbonized electricity generation are essential for leading the iron and steel industry in the USA towards decarbonization, it also shows that additional efforts are crucial for the deep decarbonization that is necessary in order to reach climate targets such as the Paris Agreement.

\section{Acknowledgement}

The authors acknowledge the financial support of the Sustainable Gas Institute, Imperial College London, and of ETH Zurich. Funding for this work is gratefully received from Royal Dutch Shell and the Newton/NERC/FAPESP Sustainable Gas Futures project NE/N018656/1. Note that funding bodies were not involved in the design, implementation or reporting of this study.

TJS thanks Innosuisse and the SCCER Heat \& Electricity Storage.

\section{References}

[dataset] IEA, 2017. Energy Technology Perspectives 2017.

[dataset] IEA, 2016. World Extended Energy Balances [WWW Document]. URL http://stats.ukdataservice.ac.uk/ (accessed 12.1.17).

[dataset] World Steel Association, 2018. Steel Statistical Yearbook [WWW Document]. URL https://www.worldsteel.org/media-centre/about-steel.html (accessed 8.15.19).

Budinis, S., 2017. Personal communication, 13th October 2017.

Budinis, S., Krevor, S., Dowell, N. Mac, Brandon, N., Hawkes, A., 2018. An assessment of CCS costs, barriers and potential. Energy Strateg. Rev. 22, 61-81. https://doi.org/https://doi.org/10.1016/j.esr.2018.08.003

Daly, H.E., Fais, B., 2014. UK TIMES Model Overview. University College London Energy Institute, London.

Edelenbosch, O.Y., Kermeli, K., Crijns-graus, W., Worrell, E., Bibas, R., Fais, B., 2017. Comparing projections of industrial energy demand and greenhouse gas emissions in long-term energy models. Energy 122, 701710. https://doi.org/10.1016/j.energy.2017.01.017

Edenhofer, O., Pichs-Madruga, R., Sokona, Y., Kadner, S., Minx, J.C., Brunner, S., Agrawala, S., Baiocchi, G., Bashmakov, I.A., Blanco, G., Broome, J., Bruckner, T., Bustamante, M., Clarke, L., Conte Grand, M., Creutzig, F., Cruz-Núñez, X., Dhakal, S., Dubash, N.K., Eickemeier, P., Farahani, E., Fischedick, M., Fleurbaey, M., Gerlagh, R., Gómez-Echeverri, L., Gupta, S., Harnisch, J., Jiang, K., Jotzo, F., Kartha, S., Klasen, S., Kolstad, C., Krey, V., Kunreuther, H., Lucon, O., Masera, O., Mulugetta, Y., Norgaard, R.B., Patt, A., Ravindranath, N.H., Riahi, K., Roy, J., Sagar, A., Schaeffer, R., Schlömer, S., Seto, K.C., Seyboth, K., Sims, R., Smith, P., Somanathan, E., Stavins, R., von Stechow, C., Sterner, T., Sugiyama, T., Suh, S., Ürge-Vorsatz, D., Urama, K., Venables, A., Victor, D.G., Weber, E., Zhou, D., Zou, J., Zwickel, T., 2014. Climate Change 2014: Mitigation of Climate Change. Contribution of Working Group III to the Fifth Assessment Report of the IPCC. Cambridge University Press, Cambridge, United Kingdom and New York, USA. 
EUROFER - The European Steel Association, 2013. A Steel Roadmap for a Low Carbon Europe 2050. Brussels.

Fais, B., Sabio, N., Strachan, N., 2016. The critical role of the industrial sector in reaching long-term emission reduction, energy efficiency and renewable targets. Appl. Energy 162, 699-712.

Fenton, M.D., 2018. U.S. Geological Survey Minerals Yearbook 2015 - Iron and Steel Scrap [Advance Release].

Fricko, O., Havlik, P., Rogelj, J., Klimont, Z., Gusti, M., Johnson, N., Kolp, P., Strubegger, M., Valin, H., Amann, M., Ermolieva, T., Forsell, N., Herrero, M., Heyes, C., Kindermann, G., Krey, V., McCollum, D.L., Obersteiner, M., Pachauri, S., Rao, S., Schmid, E., Schoepp, W., Riahi, K., 2017. The marker quantification of the Shared Socioeconomic Pathway 2: A middle-of-the-road scenario for the 21st century. Glob. Environ. Chang. 42, 251-267. https://doi.org/https://doi.org/10.1016/j.gloenvcha.2016.06.004

García Kerdan, I., Giarola, S., Hawkes, A., 2019. A novel energy systems model to explore the role of land use and reforestation in achieving carbon mitigation targets: A Brazil case study. J. Clean. Prod. https://doi.org/10.1016/j.jclepro.2019.05.345

Giarola, S., Crow, D., Hawkes, A., 2019. Simulating the carbon price trajectory in energy systems with imperfect foresight, in: IEW Proceedings IEA (Eds). Paris, France.

Global CCS Institute, 2016. The Global Status of CCS. Special Report: Introducing Industrial Carbon Capture and Storage. Melbourne, Australia.

Global CCS Institute, 2015. Fact Sheet: Capturing CO2.

Holloway, J., Roberts, I., Rush, A., 2010. China’s Steel Industry, in: Reserve Bank of Australia, Bulletin December Quarter 2010.

IEA, 2017a. World Energy Balances 2017. IEA Publications, Paris.

IEA, 2017b. Energy Technology Perspectives 2017. IEA Publications, Paris.

IEA, 2017c. Tracking Clean Energy Progress 2017. IEA Publications, Paris.

IEA, 2017d. World Energy Outlook 2017. IEA Publications, Paris.

IEA, 2014. World Energy Outlook 2014. IEA Publications, Paris.

IEA, 2009. Chemical and Petrochemical Sector - Potential of best practice technology and other measures for improving energy efficiency. IEA Publications, Paris.

IEA Energy Technology Systems Analysis Program, 2017. Energy Demand Technologies Data [WWW Document]. URL https://iea-etsap.org/index.php/energy-technology-data/energy-demand-technologiesdata (accessed 9.6.17).

IEA Energy Technology Systems Analysis Program, 2010. Technology Brief (Demand and Supply Technologies) [WWW Document]. URL https://iea-etsap.org/index.php/energy-technology-data (accessed 12.1.17).

International Institute for Applied Systems Analysis, 2016. SSP Database (Shared Socioeconomic Pathways) Version 1.1 [WWW Document]. URL https://secure.iiasa.ac.at/webapps/ene/SspDb/dsd?Action=htmlpage\&page=about (accessed 2.23.18).

International Institute for Applied Systems Analysis, 2015. Scenario Database of the Fifth Assessment Report of Working Group III of the IPCC - Version 1.0.2 [WWW Document]. URL https://tntcat.iiasa.ac.at/AR5DB (accessed 3.2.18).

IPCC, Prepared by the National Greenhouse Gas Inventories Programme, 2006. 2006 IPCC Guidelines for National Greenhouse Gas Inventories. Institute for Global Environmental Strategies, Japan, IGES, Japan.

Iyer, G., Hultman, N., Eom, J., McJeon, H., Patel, P., Clarke, L., 2015. Diffusion of low-carbon technologies and the feasibility of long-term climate targets. Technol. Forecast. Soc. Change 90, 103-118. https://doi.org/10.1016/J.TECHFORE.2013.08.025

Janetos, A.C., 2009. Science challenges and future directions: Climate Change Integrated Assessment Research.

Kempener, R., Saygin, D., 2014. Renewable Energy in Manufacturing: A technology roadmap for REmap 2030. International Renewable Energy Agency (IRENA), Abu Dhabi.

Kriegler, E., Petermann, N., Krey, V., Schwanitz, V.J., Luderer, G., Ashina, S., Bosetti, V., Eom, J., Kitous, A., Méjean, A., Paroussos, L., Sano, F., Turton, H., Wilson, C., Van Vuuren, D.P., 2015a. Diagnostic indicators for integrated assessment models of climate policy. Technol. Forecast. Soc. Change 90, 45-61. https://doi.org/10.1016/J.TECHFORE.2013.09.020

Kriegler, E., Riahi, K., Bosetti, V., Capros, P., Petermann, N., van Vuuren, D.P., Weyant, J.P., Edenhofer, O., 2015b. Introduction to the AMPERE model intercomparison studies on the economics of climate stabilization. Technol. Forecast. Soc. Change 90, 1-7. https://doi.org/10.1016/j.techfore.2014.10.012

Lechtenboehmer, S., Nilsson, L.J., Ãhman, M., Schneider, C., 2016. Decarbonising the energy intensive basic materials industry through electrification - Implications for future EU electricity demand. Energy 115, 1623-1631. https://doi.org/https://doi.org/10.1016/j.energy.2016.07.110

Loulou, R., Labriet, M., 2008. ETSAP-TIAM: The TIMES integrated assessment model Part I: Model structure. Comput. Manag. Sci. 5, 7-40. https://doi.org/10.1007/s10287-007-0046-z

McKinsey \& Company, 2018. Decarbonization of industrial sectors: the next frontier, McKinsey \& Company.

Morfeldt, J., Nijs, W., Silveira, S., 2015. The impact of climate targets on future steel production - an analysis based on a global energy system model. J. Clean. Prod. 103, 469-482. 
https://doi.org/https://doi.org/10.1016/j.jclepro.2014.04.045

Napp, T., Gambhir, A., Hills, T., Florin, N., Fennell, P., 2014. A review of the technologies, economics and policy instruments for decarbonising energy-intensive manufacturing industries. Renew. Sustain. Energy Rev. 30, 616-640. https://doi.org/https://doi.org/10.1016/j.rser.2013.10.036

National Minerals Information Center, 2017. National Minerals Information Center [WWW Document]. URL https://minerals.usgs.gov/minerals/ (accessed 9.6.17).

OECD, 2015a. The Economic Consequences of Climate Change. OECD Publishing, Paris.

OECD, 2015b. Future Investment Projects in the Global Steel Industry and Implications for the Balance of Steelmaking Processes. OECD Publishing.

RFF-CMCC European Institute on Economics and the Environment, 2019. The WITCH model [WWW Document]. URL https://www.witchmodel.org/ (accessed 8.16.19).

Rogelj, J., Shindell, D., Jiang, K., Fifita, S., Forster, P., Ginzburg, V., Handa, C., Kheshgi, H., Kobayashi, S., Kriegler, E., Mundaca, L., Gomis, M.I., Lonnoy, E., Maycock, T., Tignor, M., 2018. Mitigation Pathways Compatible with $1.5^{\circ} \mathrm{C}$ in the Context of Sustainable Development, in: Global Warming of $1.5^{\circ} \mathrm{C}$. An IPCC Special Report on the Impacts of Global Warming of $1.5^{\circ} \mathrm{C}$ above Pre-Industrial Levels and Related Global Greenhouse Gas Emission Pathways, in the Context of Strengthening the Global Response to the Threat of Climate Change,. pp. 93-174.

SSAB AB, 2016. HYBRIT - A Swedish prefeasibility study project for hydrogen based CO2-free ironmaking.

Sugiyama, M., 2012. Climate change mitigation and electrification. Energy Policy 44, 464-468. https://doi.org/https://doi.org/10.1016/j.enpol.2012.01.028

Tata Steel, 2018. HIsarna: Game Changer in the Steel Industry. Tata Steel Fact Sheet.

The Joint Global Change Research Institute, 2019. GCAM v5.1 Documentation: Global Change Assessment Model (GCAM) [WWW Document]. URL http://jgcri.github.io/gcam-doc/ (accessed 8.16.19).

The World Bank, 2018a. GDP (current US\$) [WWW Document]. URL https://data.worldbank.org/ (accessed 7.24.19).

The World Bank, 2018b. GDP growth (annual \%) [WWW Document]. URL http://www.worldbank.org (accessed 4.4.18).

United Nations Climate Change Secretariat, 2018. Climate Action Now, Summary for Policymakers 2018.

United Nations Environment Programme, 2013. Global Chemicals Outlook - Towards Sound Management of Chemicals [WWW Document]. URL

https://sustainabledevelopment.un.org/index.php?page=view\&type=400\&nr=1966\&menu=35 (accessed 9.6.17).

United Nations Framework Convention on Climate Change, 2016. The Paris Agreement. United Nations.

United Nations Statistics Division, 2017. UNdata [WWW Document]. URL http://data.un.org (accessed 12.2.17).

United States of America, 2015. Intended Nationally Determined Contribution (INDC) of the United States of America.

van der Stel, J., Meijer, K., Teerhuis, C., Zeijlstra, C., Keilman, G., Ouwehand, M., 2013. Update to the Developments of HIsarna: An ULCOS alternative ironmaking process, in: IEAGHG / IETS Iron and Steel Industry, CCUS and Process Integration Workshop.

van Ruijven, B.J., van Vuuren, D.P., Boskaljon, W., Neelis, M.L., Saygin, D., Patel, M.K., 2016. Long-term model-based projections of energy use and CO2 emissions from the global steel and cement industries. Resour. Conserv. Recycl. 112, 15-36. https://doi.org/https://doi.org/10.1016/j.resconrec.2016.04.016

van Wortswinkel, L., Nijs, W., 2010. Technology Brief I02: Iron and Steel. Paris.

Wesseling, J.H., Lechtenböhmer, S., Åhman, M., Nilsson, L.J., Worrell, E., Coenen, L., 2017. The transition of energy intensive processing industries towards deep decarbonization: Characteristics and implications for future research. Renew. Sustain. Energy Rev. https://doi.org/10.1016/j.rser.2017.05.156

Weyant, J., 2017. Some contributions of integrated assessment models of global climate change. Rev. Environ. Econ. Policy 11, 115-137. https://doi.org/10.1093/reep/rew018

Working Group III of the IPCC, 2005. IPCC Special Report on Carbon Dioxide Capture and Storage. Cambridge University Press, Cambridge, United Kingdom and New York, USA.

World Steel Association, 2019a. World Steel in Figures 2019. Brussels, Belgium. https://doi.org/https://www.worldsteel.org/dms/internetDocumentList/bookshop/2015/World-Steel-inFigures-2015/document/World\%20Steel\%20in\%20Figures\%202015.pdf

World Steel Association, 2019b. Fact Sheet: Steel and Raw Materials. Brussels, Belgium.

World Steel Association, 2019c. About Steel [WWW Document]. World Steel Assoc. URL https://www.worldsteel.org/about-steel.html (accessed 2.15.18).

World Steel Association, 2017. Global steel industry: outlook, challenges and opportunities, in: 5th International Steel Industry \& Sector Relations Conference. Istanbul.

World Steel Association, 2016a. Fact Sheet: Energy use in the steel industry. Brussels, Belgium.

World Steel Association, 2016b. Scrap Availability Model.

World Steel Association, 2012a. Sustainable steel: at the core of a green economy. Brussels, Belgium. 
World Steel Association, 2012b. Indirect trade in steel: definitions, methodology and applications. Brussels, Belgium.

Worrell, E., Price, L.K., Neelis, M., Galitsky, C., Zhou, N., 2008. World Best Practice Energy Intensity Values for Selected Industrial Sectors.

Yellishetty, M., Ranjith, P.G., Tharumarajah, A., 2010. Iron ore and steel production trends and material flows in the world: Is this really sustainable? Resour. Conserv. Recycl. 54, 1084-1094. https://doi.org/https://doi.org/10.1016/j.resconrec.2010.03.003 


\section{Appendices}

\section{A. Data Assumptions}

Table A.1. Techno-economic assumptions for calibrated technology input data to the ISM

\begin{tabular}{|c|c|c|c|c|c|}
\hline Attribute & $\begin{array}{l}\text { BF- } \\
\text { BOF }\end{array}$ & SR-BOF & DR-EAF & Scrap-EAF & Source \\
\hline $\mathrm{CAPEX}^{1}$ & 1.00 & 1.03 & 0.62 & 0.43 & $\begin{array}{l}\text { (Morfeldt et al., 2015; van Ruijven et al., } \\
\text { 2016) }\end{array}$ \\
\hline $\mathrm{OPEX}^{1}$ & 1.00 & 4.05 & 0.44 & 0.94 & (Morfeldt et al., 2015) \\
\hline SEC (Fuel) ${ }^{1}$ & 1.00 & 1.20 & 1.07 & 0.05 & $\begin{array}{l}\text { (IEA, 2017b, 2009; IEA Energy } \\
\text { Technology Systems Analysis Program, } \\
\text { 2017; Worrell et al., 2008) }\end{array}$ \\
\hline $\begin{array}{l}\text { SEC } \\
\text { (Electricity) }{ }^{1}\end{array}$ & 1.00 & 0.61 & 2.32 & 4.18 & $\begin{array}{l}\text { (Morfeldt et al., 2015; Worrell et al., } \\
\text { 2008) }\end{array}$ \\
\hline $\begin{array}{l}\mathrm{CO}_{2} \text { emission } \\
\text { from chemical } \\
\text { processes }^{1}\end{array}$ & 1.00 & 0.60 & 0.06 & 0.06 & (Daly and Fais, 2014) \\
\hline $\begin{array}{l}\text { Technical } \\
\text { lifetime }\end{array}$ & 25 years & 25 years & 25 years & 25 years & $\begin{array}{l}\text { (Daly and Fais, 2014; Morfeldt et al., } \\
\text { 2015) }\end{array}$ \\
\hline UF & $90 \%$ & $90 \%$ & $90 \%$ & $90 \%$ & (Budinis, 2017) \\
\hline \multicolumn{6}{|l|}{$\begin{array}{l}\text { Plants with } \\
\text { integrated CCS }\end{array}$} \\
\hline $\begin{array}{l}\text { CAPEX \& } \\
\text { OPEX }(2010)^{2}\end{array}$ & 1.48 & 1.48 & 1.48 & 1.48 & $\begin{array}{l}\text { (IEA Energy Technology } \\
\text { Analysis Program, 2010) }\end{array}$ \\
\hline $\begin{array}{l}\text { CAPEX \& } \\
\text { OPEX }(2020)^{2}\end{array}$ & 1.40 & 1.40 & 1.40 & 1.40 & $\begin{array}{l}\text { (IEA Energy Technology Systems } \\
\text { Analysis Program, 2010) }\end{array}$ \\
\hline $\begin{array}{l}\text { CAPEX \& } \\
\text { OPEX }(2030)^{2}\end{array}$ & 1.32 & 1.32 & 1.32 & 1.32 & $\begin{array}{l}\text { (IEA Energy Technology Systems } \\
\text { Analysis Program, 2010) }\end{array}$ \\
\hline $\begin{array}{l}\text { Efficiency } \\
\text { penalty }^{2}\end{array}$ & $12 \%$ & $12 \%$ & $12 \%$ & $12 \%$ & $\begin{array}{l}\text { (IEA Energy Technology Systems } \\
\text { Analysis Program, 2010) }\end{array}$ \\
\hline $\begin{array}{l}\mathrm{CO}_{2} \text { capture } \\
\text { rate }\end{array}$ & $90 \%$ & $90 \%$ & $90 \%$ & $90 \%$ & $\begin{array}{l}\text { (IEA, 2017b; Working Group III of the } \\
\text { IPCC, 2005) }\end{array}$ \\
\hline
\end{tabular}

Table A.2. Assumptions for fuel input data to the ISM

\begin{tabular}{|c|c|c|c|c|c|c|c|c|c|}
\hline Attribute & $\begin{array}{l}\text { Hard } \\
\text { coal }\end{array}$ & $\begin{array}{l}\text { Bio- } \\
\text { methane }\end{array}$ & $\begin{array}{l}\text { Electri- } \\
\text { city }\end{array}$ & $\begin{array}{l}\text { Forest } \\
\text { residues }\end{array}$ & $\mathrm{HFO}$ & LPG & Naphtha & $\begin{array}{l}\text { Natural } \\
\text { gas }\end{array}$ & Source \\
\hline $\begin{array}{l}\mathrm{CO}_{2} \text { emission } \\
\text { factors from fuel } \\
\text { combustion }^{1}\end{array}$ & 1.00 & 0.58 & $0.00^{2}$ & 1.18 & 0.82 & 0.67 & 0.77 & 0.59 & $\begin{array}{l}\text { (IPCC, } \\
\text { 2006) }\end{array}$ \\
\hline Fuel prices ${ }^{3}$ & & & & & & & & & $\begin{array}{l}\text { (IEA, } \\
\text { 2017d) }\end{array}$ \\
\hline 2010 & 1.00 & 1.65 & 6.97 & 7.09 & 5.61 & 9.41 & 7.36 & 2.50 & \\
\hline 2030 & 1.16 & 1.74 & 12.48 & 7.51 & 7.02 & 11.77 & 9.20 & 3.39 & \\
\hline 2050 & 1.10 & 1.88 & 11.33 & 8.11 & 6.73 & 11.29 & 8.83 & 3.37 & \\
\hline
\end{tabular}

Note. ${ }^{1}$ Values have been scaled in reference to the hard coal.

${ }^{2}$ The specific $\mathrm{CO}_{2}$ emission from electricity generation are scenario- and time-dependent and have been reported in Table 3 .

${ }^{3}$ Values have been scaled in reference to the price of hard coal in 2010. 